\title{
KUALITAS PENANGANAN PENGADUAN TINDAK KEKERASAN PADA ANAK DAN PEREMPUAN DI UNIT PERLINDUNGAN PEREMPUAN DAN ANAK POLDA KALTENG
}

\section{Quality of Handling Complaints of Violence Against Children and Women in the Protection Unit of Women and Children of the Central Kalimantan Regional Police}

\section{Shanty Bahar Ising* Ayudita Trapsilo Jati}

Universitas Muhammadiyah Palangkaraya, Palangka Raya, Central Kalimantan, Indonesia

email: shanty.bahar@umpalangkaraya.ac.id

\section{Kata Kunci:}

Impelementasi

Kebijakan

Pengelolaan

Sanitasi

\section{Keywords:}

Implementation

Policy

Management

Sanitation

\section{Accepted}

June 2017

\section{Published}

Oktober 2017

\begin{abstract}
Abstrak
Penelitian ini bertujuan untuk mengetahui bagaimana kualitas pengangan pengaduan tindak kekerasan pada anak dan perempuan di Unit PPA Polda Kalteng.Metode yang digunakan adalah metode Kualitatif, penelitian yang dilakukan merupakan penelitian deskriptif dimana Unit PPA Polda Kalteng sebagai lokasi penelitian. Teknik pengumpulan data menggunakan Observasi, wawancara dan dokumentasi.
\end{abstract}

Berdasarkan hasil penelitian menunjukkan bahwa Kualitas Penanganan pengaduan Tindak Kekerasan pada Anak dan Perempuan Unit PPA Polda Kalteng masih belum maksimal, karena dari lima indikator kualitas pelayanan ada dua indikator yang belum berjalan dengan baik yaitu Tangibles, dan Responsiveness sedangkan tiga indikator yang sudah berjalan dengan baik adalah indikator realibility, Assurance dan Emphaty.

\begin{abstract}
This study aims to find out how the quality of complaints of acts of violence against children and women in the Central Kalimantan Regional Police PPA Unit. The method used is the Qualitative method, the research conducted was descriptive research in which the Central Kalimantan Regional Police PPA Unit was the research location. Data collection techniques use observation, interviews, and documentation.

Based on the results of the study, the Quality of Handling Complaints on Violence Against Children and Women of the Central Kalimantan Regional Police PPA Unit is still not optimal, because of the five service quality indicators there are two indicators that have not run well, namely Tangibles, and Responsiveness while the three indicators that have gone well are reliability indicator, Assurance, and Empathy.
\end{abstract}

\section{PENDAHULUAN}

Pelecehan dan kekerasan seksual terhadap anak di Tanah Air meningkat 100 persen dari tahun-tahun sebelumnya. Catatan Komisi Perlindungan Anak Indonesia (KPAI) menyebutkan, angka korban pelecehan seksual terhadap anak semakin tinggi setiap tahun. Dari 2013 ke 2014 itu naiknya 100 persen, baik itu mereka yang jadi korban atau pun pelaku. Modus pelecehan seksual semakin beragam dan aneh. Hal-hal yang tak terduga dapat terjadi. Selain kemajuan teknologi dan kurangnya pengetahuan orangtua dalam mengasuh dan mendidik anaknya, lingkungan pergaulan juga menjadi penyebabnya.

Kasus yang mendominasi di Kalimantan Tengah kebanyakan adalah kasus persetubuhan anak di bawah umur yang melibatkan anak sebagai korban maupun anak sebagai korban sekaligus pelaku kekerasan tersebut. kemudian kasus kekerasan dalam rumah tangga yang terjadi dengan korban perempuan yang rata-rata diakibatkan karena faktor ekonomi ataupun 
adanya pihak ketiga dalam berumah tangga. Selanjutnya kasus penganiayaan yang terjadi dengan korban dan pelaku anak dikarenakan faktor hubungan asmara.

Dalam penanganan kasus perempuan dan anak di Unit PPA Polda Kalteng untuk saat ini masih belum sesuai dengan yang seharusnya dengan Pelayanan yang sesuai Standar Operasional Unit PPA Polda Kalteng. Dimana penanganan kekerasan pada perempuan dan anak yang seharusnya perlu penanganan cepat tetapi kenyataanya masyarakat atau pelapor pun masih menunggu keputusan hukum yang jelas dari pihak kepolisian yaitu apakah itu termasuk perlu penanganan hukum atau bisa diselesaikan dengan musyawarah saja. Hal genting kasus perempuan dan anak memang menjadi atensi publik yang harus segera ditangani.

Konsep kualitas bersifat relatif, karena penilaian kualitas sangat ditentukan dari prespektif yang digunakan. Menurut Trilestari (2004:5) pada dasarnya terdapat tiga orientasi kualitas yang seharusnya konsisten antara yang satu dengan yang lain, yaitu presepsi pelanggan, produk dan proses. Untuk produk jasa pelayanan, ketiga orientasi tersebut dapat menyumbangkan keberhasilan organisasi ditinjau dari kepuasan pelanggan. Dari sepuluh dimensi kualitas pelayanan, kemudian Zeithaml V.A \& Berry menyederhanakan menjadi lima dimensi, yaitu :

I. Bukti Langsung (Tangibles), Kualitas pelayanan berupa sarana fisik perkantoran, komputerisasi administrasi, ruang tunggu, tempat informasi.

2. Kehandalan (Reliability), Kemampuan dan keandalan untuk menyediakan pelayanan yang terpercaya.

3. Daya tanggap (Responsivess), Kesanggupan untuk membantu dan menyediakan pelayanan secara cepat dan tepat, serta tanggap terhadap keinginan konsumen.
4. Jaminan (Assurance), Kemampuan dan keramahan serta sopan santun pegawai dalam meyakinkan kepercayaan konsumen.

5. Empati (Empaty), Sikap tegas tetapi penuh perhatian dari pegawai terhadap konsumen.

\section{METODOLOGI}

Metode penelitian yang penulis gunakan adalah metode penelitian kualitatif. Penelitian kualitatif adalah penelitian tentang riset yang bersifat deskriptif dan cenderung menggunakan analisis. Proses dan makna (perspektif subyek) lebih ditonjolkan dalam penelitian kualitatif. Landasan teori dimanfaatkan sebagai pemandu agar fokus penelitian sesuai dengan fakta di lapangan. Selain itu landasan teori juga bermanfaat untuk memberikan gambaran umum tentang latar penelitian dan sebagai bahan pembahasan hasil penelitian. penelitian ini menggunakan metode kualitatif, dengan alasan dengan melalui penelitian ingin mengetahui fenomena yang terjadi untuk memberikan gambaran secara jelas mengenai masalah yang diteliti, mengidentifikasikan dan menjelaskan data yang ada secara sistematis. Tipe deskriptif didasarkan pada peristiwa-peristiwa yang terjadi pada saat peneliti melakukan penelitian kemudian menganalisanya dan membandingkan dengan kenyataan yang ada dengan teori, dan selanjutnya menarik kesimpulan.

\section{HASIL DAN PEMBAHASAN}

Pelayanan berkualitas sangat dibutuhkan oleh masyarakat, aparatur penegak Hukum sebagai pelayan masyarakat harus selalu mengutamakan kepentingan masyrakat unruk terciptanya Pelindung, Pengayom dan Pelayan Masyarakat, Kualitas Pelayanan yang dapat diukur dari 5 (lima) indikator seperti : Berwujud (Tangible), Kehandalan (Realibility), Ketanggapan (Responsiviness), Jaminan (Assurance) dan Empati (Emphaty). Berdasarkan hasil penelitian di lapangan dan berdasarkan kesesuaian dengan indikator Zeithaml, 
Kualitas penanganan pengaduan tindak kekerasan pada anak dan perempuan di Unit PPA Polda Kalteng masih belum maksimal dan dapat dijelaskan sebagai berikut :

\section{Berwujud (Tangible)}

Tangible berkaitan dengan fasilitas fisik, penampilan petugas sarana prasarana yang digunakan dalam memberikan pelayanan. Dari hasil penelitian di lapangan penampilan petugas di Unit PPA Polda Kalteng sudah rapi, sopan dan sesuai dengan pakaian yang digunakan sebagaimana mestinya anggota Reskrim. Untuk sarana dan prasarana unit PPA polda kalteng juga belum maksimal. Karena masih ada keluhan dari masyarakat yang dimana seperti kurangnya fasilitas Televisi, dan Wifi. Masyarakat merasa jenuh saat menunggu giliran pemeriksaan oleh penyidik. Serta fasilitas fisik yang belum maksimal, Unit PPA Polda Kalteng belum memiliki ruang pelayanan khusus (RPK). Ruang tersebut sangat diperlukan untuk menunjang pelayanan di Unit PPA Polda Kalteng. Ruang tersebut digunakan untuk beristirahat korban disaat korban masih trauma dan memerlukan istirahat sebelum dilakukan pemeriksaan oleh penyidik.

2. Kehandalan (Reability)

Reability yang berarti bahwa pelayanan harus tepat waktu dan dalam spesifikasi yang sama tanpa kesalahan, kapanpun pelayanan tersebut diberikan. Dari hasil penelitian di lapangan dalam memberikan pelayanan pengaduan tindak kekerasan pada perempuan dan anak Unit PPA Polda Kalteng sudah maksimal. Tidak membedabedakan atau diskriminasi terhadap siapapun yang datang melapor, semua dilayani sama. Pelayanan yang diberikan Unit PPA Polda Kalteng memberikan pelayanan yang prima dalam waktu Ix24 jam setiap ada kasus yang harus segera ditangani maka Unit PPA Polda Kalteng siap untuk segera memproses. Unit PPA Polda Kalteng juga sudah memberikan pelayanan yang sesuai dengan apa yang diadukan atau dikeluhkan oleh pelapor. Semua diproses sesuai dengan Tindak Pidana atau unsur yang masuk dalam pasal yang berlaku.

3. Ketanggapan (Responsiviness)

Responsiveness yang berkaitan dengan kemampuan dari petugas membantu masyarakat atau pelapor dalam memeberikan layanan dengan tanggap dalam hal ini yang dimaksud adalah petugas Unit PPA Polda Kalteng dan masyarakat atau pelapaor yang melapor tindak pidana. Responiveness atau Ketanggapan dari petugas dalam memberikan pelayanan belum maksimal. Karena dalam pelayanan masih belum berjalan sesuai dengan standar operasional prosedur. Masih ada keluhan dari masyrakat tentang pelayanan petugas kepada masyarakat atau pelapor. Misalnya dalam penangana kasus yang lambat. Penanganan kasus yang lambat disebabkan karena saksi yang belum ada, bukti yang belum menguatakan untuk menentukan itu sebuah tindak pidana, serta kasus tersebut merupakan kasus yang belum sama sekali menemukan titik temu atau lambatnya proses mediasi / jalur dimana penyelesaian masalah yang diluar hukum, masih banyak kasus lain yang harus diselesaikan oleh penyidik. Bahkan ada pelapor yang tidak kooperatif dalam pelaporan kebanyakan dari kasus kekerasan dalam rumah tangga. Yang dimana saat melapor dalam keadaan emosi tidak terkontrol dan segera untuk meminta penyidik untuk memproses dan memenjarakan pelaku. Namun setelah proses jalannya perkara ditengah jalan pelpaor tidak dapat dihubungi lagi dan tidak mau memenuhi panggilan dari penyidik. Dengan alasan mereka sudah rujuk kembali.

4. Jaminan (Assurance)

Jaminan (assurance) yaitu kemampuan dan kesopanan petugas serta sifat dapat dipercaya yang dimiliki oleh petugas. Jaminan menyangkut pengetahuan, kesopansantunan, kemampuan para 
petugas untuk menumbuhkan rasa percaya masyarakat atau pelapor pada pelayanan yang diberikan. Dari hasil penelitian di lapangan petugas sudah memberikan kepastian hukum atau legalitas hukum awal berupa surat tanda penerimaan laporan yang berarti masyarakat tersebut sudah sah melakukan pelaporan di Unit PPA Polda Kalteng. Kemudian masyarakat pun dalam berjalannya proses perkara tetap akan diberikan surat yang isinya melaporkan tiap perkembangan kasus yang di tangani oleh Unit PPA Polda Kalteng. Surat pemberitahuan perkembangan hasil penyidikan Al dimana surat tersebut berisikan bahwa laporan pengaduan dari masyarakat yang diterima kemudian dilakukan analisa apakah termasuk dalam unsur pidana atau bukan. Surat tersebut dibuat agar masyarakat tetap yakin bahwa laporan mereka ditangani dan di proses oleh penyidik Unit PPA Polda Kalteng.

5. Empati (Emphaty)

Emphaty yaitu kemudahan dalam melakukan hubungan verbal antara petugas dengan masyarakat dalam proses pemberi pelayanan, komunikasi yang baik, serta perhatian pribadi dan memahami kebutuhan masyarakat.

Berdasarkan hasil penelitian di lapangan petugas di Unit PPA Polda Kalteng dalam menangani perkara juga merasakan empati bagi korban korban yang mengalami tindak pidana kekerasan. Namun petugas tidak boleh juga larut dalam akan kesedihan yang dirasakan oleh pelapor. Petugas tetap memberikan saran mana yang terbaik diambil sebelum benar-benar untuk memutuskan menempuh jalur hukum. Petugas Unit PPA Polda Kalteng dalam memberikan pelayanan dengan bersikap sopan, ramah dan menghargai siapapun yang datang melapor. Selalu mendahulukan kepentingan masyarakat yang datang melapor sebagai wujud dari pelayanan prima anggota polri.

\section{KESIMPULAN}

Berdasarkan hasil penelitian dan pembahasan menunjukkan bahwa Kualitas Pelayanan Penanganan Terutama pada Ketanggapan Petugas dalam memberikan Pelayanan Pengaduan Tindak Kekerasan Terhadap Anak Dan Perempuan Di Unit PPA Polda Kalteng masih belum maksimal karena masih banyak kasus lain yang harus diselesaikan oleh penyidik dengan keterbatasan jumlah penyidik. Kemudian belum cepatnya dalam penanganan kasus-kasus yang ada dikarenakan petugas perlu jangka waktu untuk melakukan koordinasi dengan instansi lain, selain itu juga pelapor atau masyarakat dan terlapor yang kurang kooperatif dengan petugas sehingga menghambat kecepatan proses penyelesaian perkaranya.

Sarana dan Prasarana yang ada di Unit PPA Polda Kalteng juga belum memadai. Belum adanya Ruang Pelayanan Khusus (RPK) untuk penanganan korban baik anak maupun perempuan. Unit PPA Polda Kalteng masih menunggu giliran dalam hal pembangunan Ruang Pelayanan Khusus (RPK) tersebut dari Mabes Polri dimana Mabes Polri juga melakukan evaluasi tehadap tingkat kerawanan tindak kekerasan pada perempuan dan anak di masingmasing wilayah. Adapun saran yang dapat peneliti berikan adalah sebagai berikut :

I. Penyidik bisa cepat tanggap saat ada kasus yang melibatkan perempuan dan anak agar tidak terjadi komplain. Petugas bisa langsung mengambil keputusan seusai dengan standar operasional prosedur yang berlaku tanpa menunggu untuk keputusan dari pimpinan. Petugas atau penyidik dapat mengambil keputusan dengan petugas yang lebih berpengalaman atau yang lebih mengerti dengan kasus yang ditangani. Sehingga dapat memberikan masukan kepada pimpinan bahwa kasus anak dan perempuan menjadi perhatian publik.

2. Petugas atau penyidik dapat melakukan koordinasi dengan Dinsos untuk melakukan pemulihan 
psikologi terhadap korban setelah mengalami trauma akan tindak pidana yang dialaminya dan setelah dilakukan pemeriksaan oleh penyidik agar tidak menjadi beban pikiran korban terus menerus.

3. Unit Perlindungan Perempuan dan Anak (UPPA) Polda Kalteng melakukan pengajuan anggaran belanja untuk pembangunan tiap tahunnya ke Badan Biro Perencanaan dalam hal pembuatan ruang pelayanan khusus (RPK) agar meneruskan ke Mabes Polri untuk menunjang pelayangan pengaduan di Unit PPA Polda Kalteng.

\section{REFERENSI}

Abdul Wahab, Solichin. 2010. Analisis Kebijaksanaan dari Formulasi ke Implementasi Kebijaksanaan Negara, Jakarta: BumiAksara.

Buku Perlindungan terhadap perempuan dan anak yang menjadi korbankekerasan dengan mengoptimalkan sistem peradilan pidana terpadu (SPPT) yang Responsif Gender Edisi ke 3.

Harahap, Tuti Khairani 2009. Faktor-Faktor yang Mempengaruhi Implementasi Kebijakan UndangUndang Nomor 23 Tahun 2002 Pasal 13 Ayat I (D) tentang Perlindungan Anak. Jurnal Sorot, 4 (I)

Hardiasnyah.20 I I. Kualitas Pelayanan Publik.Yogyakarta: Gava Media.

Ghony \& Fauzan Almanshur. 2016. Metode Penelitian Kualitatif. Jogjakarta: Ar.Ruzz Media.

Komisi Perlindungan Anak Indonesia. 20II. Data Informasi dan pengaduan 2016. Tersedia pada : http://www.kpai.go.id/
LAN, 2003. Dimensi Pelayanan Publik dan Tantangannya Dalam Administrasi Negara (Publik) di Indonesia. Jakarta: Bagian Humas dan Publikasi.

Moleong, Lexy J. Metode Penelitian Kualitatif Edisi Revisi. Bandung : PT remaja Rosidakarya

Pasolong, Harbani. 20I3. Teori Administrasi Publik. Bandung : Alvabeta.

Peraturan Kapolri Nomor 3 Tahun 2008 tentang pembentukan ruang pelayanan khusus dan tata cara pemeriksaan saksi dan korban.

Sianipar. 2008. Manajemen Pelayanan Masyarakat. LAN. Jakarta.

Supranto, J. 200I. Pengukuran Tingkat Kepuasan Pelanggan: Untuk Menaikkan Pangsa Pasar. Jakarta: Rineka Cipta.

Sugiyono. 2005. Memahami Penelitian Kualitatif. Bandung : Alfabeta

Tjiptono, Fandy. 200I. Kualitas Jasa, J \& J Learning. Yogyakarta:Andi Offset.

Tjiptono, Fandy. 2015. Strategi Pemasaran, Edisi 4. Yogyakarta : Penerbit Andi.

Trilestari, Endang Wirjatmi. 2004. Model Kinerja Pelayanan Publik dengan Pendekatan Systems Thinkinks and System Dinamics. Disertasi. Depok: FISIP UI.

Undang-Undang Nomor 23 Tahun 2002 Tentang Perlindungan Anak 